\title{
Mediating Role of Knowledge Management in the Relationship Between Organizational Learning and Sustainable Organizational Performance
}

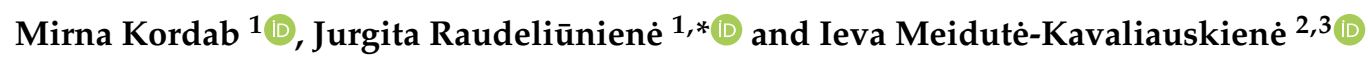 \\ 1 Department of Business Technologies and Entrepreneurship, Vilnius Gediminas Technical University, \\ LT-10223 Vilnius, Lithuania; mirna.kordab@vgtu.lt \\ 2 Research Group on Logistics and Defense Technology Management, General Jonas Žemaitis Military \\ Academy of Lithuania, Silo st. 5A, LT-10322, Vilnius, Lithuania; ieva.meidute@lka.lt \\ 3 Business Research Unit (BRU-IUL), Instituto Universitário de Lisboa (ISCTE-IUL), 1649-026, Lisboa, Portugal \\ * Correspondence: jurgita.raudeliuniene@vgtu.lt
}

Received: 22 October 2020; Accepted: 1 December 2020; Published: 2 December 2020

\begin{abstract}
Organizations operating in the intensive knowledge-based sector seek efficient management approaches and sustainable development practices to perform efficiently in the dynamic business environment. Knowledge management practice and organizational learning are significant factors in order to achieve sustainable organizational performance in a rapidly changing business environment. Based on the scientific literature analysis, there is still a lack of evidence related to the mediating role of the whole knowledge management cycle, including the five knowledge management processes (knowledge acquisition, creation, storage, sharing, and application) in the relationship between organizational learning and sustainable organizational performance for organizations operating in intensive knowledge-based sectors. This study aimed to examine the impact of the whole knowledge management cycle on the relationship between organizational learning and sustainable organizational performance in intensive knowledge-based sectors, specifically the audit and consulting companies in the Middle East region. Systematic scientific literature analysis, expert evaluation (structured questionnaire), and structural equation modeling (SEM) technique were used to develop and verify the research model. Data was collected through a structured questionnaire distributed among auditing experts working in a knowledge-based sector-audit and consulting companies in the Middle East region. The research results supported the hypotheses stating that organizational learning positively affects knowledge acquisition, storage, sharing, application processes, and sustainable organizational performance. However, the results verified that organizational learning has an insignificant impact on the Middle Eastern audit and consulting companies' knowledge creation process.
\end{abstract}

Keywords: organizational learning; knowledge management; knowledge management cycle; sustainable organizational performance; knowledge-based sector; audit and consulting companies

\section{Introduction}

The dynamic changes in the business environment and transformational processes related to environmental, social, and economic issues have created new challenges for organizations operating in the intensive knowledge-based sector. Organizations are looking for efficient knowledge management and organizational learning practices and tools in order to adapt quickly to those changes from inner and outer perspectives, satisfy continuously changing business customers' knowledge demand, improve their sustainable organizational performance, and seek local and global leadership [1-3].

The knowledge-based sector is intensive in its inputs and outcomes of a combination of intellectual capital and technology. This sector plays an increasing role in current advanced economies, 
and its contribution to the business value-added of the developed economies grows constantly. The knowledge-based industry provides knowledge-intensive activities based on their occupational structures, and organizations operating in the knowledge-based sector integrate and apply knowledge to detect, explore, and address environment dynamics [4,5]. Besides, the intensive knowledge-based sectors perceive the intellectual resources as enablers of sustainable performance where knowledge is considered the organization's primary asset. The effective management of knowledge benefits those organizations from a reduction in the human and infrastructure costs and an improvement in the innovation, efficiency, and effectiveness of their operations, leading to a sustainable organizational performance [6-9]. Organizational learning affects the organization's business processes and the flows of knowledge that increase innovation and improve overall organizational performance and leadership [10-13].

Previous studies have recognized organizational learning as an essential factor influencing knowledge management processes, such as knowledge acquisition, creation, storage, transfer, and utilization, positively [14-16]. Besides, based on the previous studies' results, these effective implementation processes positively affect sustainable organizational performance [17-20]. However, there are some limitations in previous investigations. For instance, in earlier explorations, only limited knowledge management processes were analyzed in the intensive knowledge-based sector. This fact has created a gap related to studying the mediating role of the whole knowledge management cycle, including the five knowledge management processes-acquisition, creation, storage, sharing, and application-in the relationship between organizational learning and sustainable organizational performance.

This study aimed to examine the impact of the whole knowledge management cycle (acquisition, creation, storage, sharing, and application) on the relationship between organizational learning and sustainable organizational performance in intensive knowledge-based sectors, specifically the audit and consulting companies in the Middle East region.

The Middle East region in this study was selected for several main factors. One reason is connected to the lack of studies that have been analyzed in this area in the intensive knowledge-based industries and accurately in the audit and consulting field. The secondreason is related to globalization's challenges in the Middle East region, connected to possibilities to explore knowledge management potential in the intensive knowledge-based sectors as the audit and consulting for sustainable development.

Systematic scientific literature analysis, structural equation modeling, and expert evaluation (structured questionnaire) were used to develop and verify the research model. The data was collected from experts operating in audit and consulting companies located in the Middle East region, including Lebanon, Syria, and Jordan, where associations of Certified Public Accountants exist.

Study results have demonstrated that if audit and consulting companies' managers use organizational learning through four knowledge management processes as knowledge acquisition, storage, sharing, and application, this relationship positively affects sustainable organizational performance in the audit and consulting sector. This study's value and originality are linked to the analysis of the whole knowledge management cycle by integrating five knowledge management processes. Furthermore, this study was conducted based on an expert survey and organizational learning contribution concerning the entire knowledge management cycle and sustainable organizational performance in the intensive knowledge-based sector as the audit and consulting companies in developing countries such as the Middle East region. Study results will enrich scientists and business practitioners' perspectives via an intensive knowledge-based area with a perception of how organizational learning through the whole knowledge management cycle contributes to sustainable organizational performance.

\section{Literature Review}

Organizational learning is a collective multilevel process consisting of psychological and social processes involving intuition, interpretation, integration, and institutionalization of knowledge [21-23], the transformation of the tacit knowledge into explicit knowledge [12,13,24], and support of knowledge exchange between individuals and groups [11,22,25]. As defined by Fiol and Lyles (1985), organizational 
learning means the process of improving actions through knowledge and perception [26]. Organizational learning provides individuals with relevant personal, professional, and social competencies [9] and experiences $[23,25,27]$. This potential helps them respond more efficiently to environmental changes $[13$, $24,25]$ and contribute to creating the organization's value, improving its operations' effectiveness and efficiency, and achieving a sustainable organizational performance [17-19]. Organizational learning involves a set of knowledge management processes that facilitate the acquisition, creation, storage, sharing, and application of knowledge between individuals and groups at all organizational levels. Besides, it positively affects sustainable organizational performance through enhancing staff competencies for efficient problem solving and decision making, knowledge strategy achieving, and local and global leadership. Kump et al. (2015) analyzed the cognitive foundations of organizational learning to find that collective declarative knowledge could be developed through verbal communication at the organizational level. However, collective non-declarative knowledge is based on repetitive practices where collaboration between individuals in mutual tasks may improve individual expertise and skills. The distinction between declarative and non-declarative knowledge provides a better perception of practical problems related to organizational learning and change [28].

Knowledge is a crucial asset and a critical organizational resource $[29,30]$. It is a combination of personal judgment, values, competencies, capabilities, know-how, and techniques [31,32]. Knowledge management is characterized by knowledge strategies and processes implemented in the organization to increase the effectiveness and efficiency of business processes, achieve knowledge strategy, and sustain organizational performance [33-36].

Researchers and business developers have analyzed and implemented different knowledge management processes [37-41]. Based on the earlier studies results of J. Raudeliūnienè [9,42-45] and the outcomes of discussion with audit and consulting companies experts in the Middle East region, this research analyzed the whole knowledge management cycle, consisted of knowledge acquisition, creation, sharing, storage, and application. These five knowledge management processes were selected because they were applied in audit and consulting companies' activities to achieve sustainability.

Based on previous studies' results, which were focused on the relationship between organizational learning and knowledge management processes, it is essential to state that there is a lack of organizational learning studies on the whole knowledge management cycle. Previous studies have demonstrated the positive effect of organizational learning on specific knowledge management processes in certain industries in Bosnia and Herzegovina [14], and Indonesia [16]. These studies' main limitations were related to the small generalizability of the findings, since investigations were conducted in one country and in the specific sectors of education and tourism. Based on previous research limitations, this study focused on audit and consulting companies as an intensive knowledge-based sector in the Middle East region to examine the whole knowledge management cycle and determine how this cycle is affected by organizational learning.

Knowledge acquisition is described as capturing and gathering knowledge from inside and outside sources [46-48]. These sources involve the internal and external interaction between employees, suppliers, customers, and consultants in order to determine and reduce the knowledge gaps inside the organization $[8,49,50]$. Knowledge acquisition enhances the organization's competencies to obtain the knowledge that would improve problem-solving and the decision-making processes, operational business processes to achieve the desired performance [47,50,51]. Knowledge acquisition can be defined as the accumulation of various knowledge types from different sources to eliminate knowledge gaps to achieve knowledge strategy and increase sustainable organizational performance. Based on previous studies linked to the relationship between organizational learning and the knowledge acquisition process, Wahda (2017) has verified the positive effect of organizational learning on knowledge acquisition in the Indonesian education sector [16]. Furthermore, Turulja and Bajgorić (2018) have reached the same outcome in medium and large companies in Bosnia and Herzegovina market [14]. However, these studies have had some limitations related to the specific analyzed sectors and the particular geographic area where the studies were conducted. In order to test the positive 
impact of organizational learning on knowledge acquisition in audit and consulting companies in the Middle East region, the following hypothesis was formulated (Figure 1):

Hypothesis 1a (H1a). Organizational learning affects the knowledge acquisition process positively.

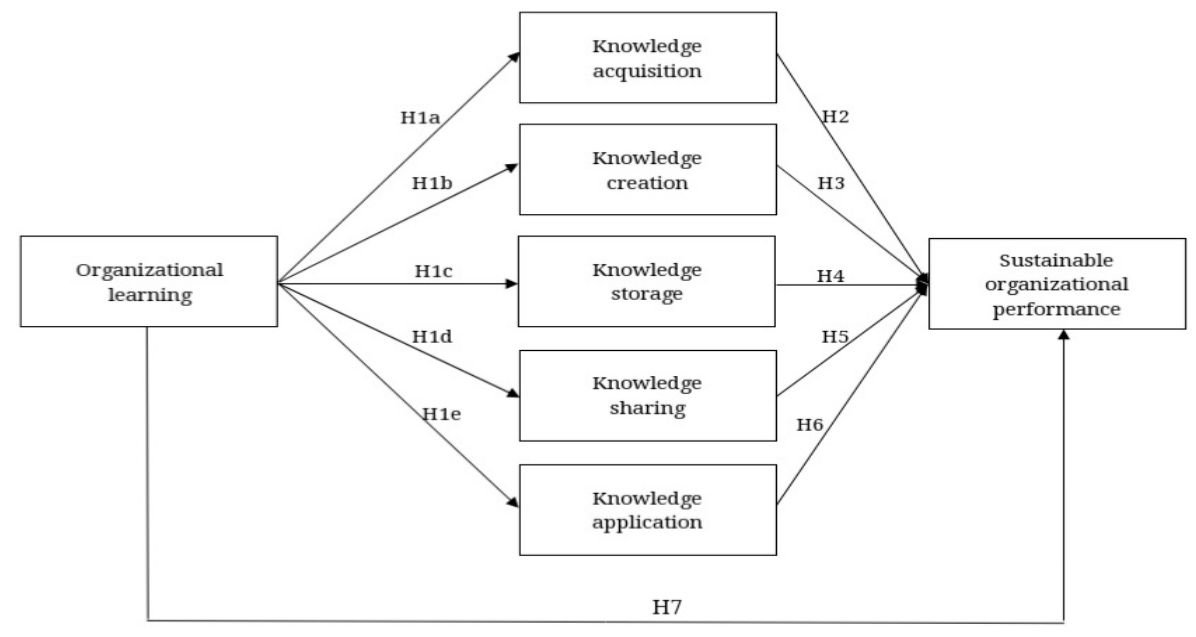

Figure 1. Research model.

Knowledge creation is characterized as developing new competencies (knowledge, abilities, and skills) and expertise within the organization [6,32,52]. It consists of research concerning the market, products, and services that lead to advanced unique ideas and opportunities $[47,53,54]$. This process would improve the organization's innovation, uniqueness, and leadership, enhancing overall organizational performance [55-57]. Knowledge creation can be described as the generation of new substances and competencies that lead to achieving knowledge strategy and sustainable organizational performance. Previous studies linked to the relationship between organizational learning and knowledge creation are minimal. Wahda (2017) has investigated the positive impact of organizational learning on the Indonesian education sector's knowledge creation process. Nonetheless, this research has limitations related to the specifics of the educational sector [16]. In order to fulfill the deficiencies in previous studies, the following hypothesis was proposed (Figure 1):

Hypothesis $\mathbf{1 b}(\mathbf{H} 1 \mathbf{b})$. Organizational learning affects the knowledge creation process positively.

Knowledge storage is described as selecting and organizing the individuals' knowledge and expertise, and the organization's strategies, systems, and manuals, to save them in the organization's repositories [32,53,55]. Knowledge storage contributes to transforming tacit knowledge into explicit knowledge and turning it into an organization's resource accessible through adequate databases, networks, and information technology tools $[6,47,58]$. Knowledge should be organized and stored to protect its value from loss and benefit from it by enhancing the efficiency of the organization's activities and improving its performance $[37,47,54]$. Knowledge storage can be determined as the recording and preservation of the available knowledge in the organization's databases and repositories, which lead to increasing work efficiency, achieving knowledge strategy, and improving sustainable organizational performance. Based on Antunes and Pinheiro's (2020) research results, organizational memory results from organizational learning, where one of the organizational memory processes is knowledge storage. Researchers underlined that the usage of organizational memory has consequences on organizational performance [59]. The main limitation of this study is related to the type of research-a systematic literature review. In order to verify if organizational learning has a significant impact on knowledge storage, the following hypothesis was formed (Figure 1):

Hypothesis 1c (H1c). Organizational learning affects the knowledge storage process positively. 
Knowledge sharing is defined as the transfer and exchange of competencies (knowledge, abilities, and skills) between individuals, groups, or organizations $[38,60,61]$. As a result of disseminating knowledge between parties, the organization's capabilities could improve, and essential processes such as problem-solving, decision making, uniqueness, leadership, efficiency, and innovation could increase $[40,41,62]$. Knowledge sharing can be described as the exchange of both tacit and explicit knowledge between various parties by using different tools, facilitating the achievement of knowledge strategy and increasing sustainable organizational performance. Based on previous researches results, Wahda (2017) verified the positive relationship between organizational learning, knowledge sharing and organizational effectiveness in the education sector in Indonesia [16]. Limitations of this study were linked to one case analysis in a specific region. In order to verify the significant impact of organizational learning in the intensive knowledge-based sector on the knowledge sharing process, the following hypothesis was created (Figure 1):

Hypothesis 1d (H1d). Organizational learning affects the knowledge sharing process positively.

Knowledge application is characterized by the appropriate usage of knowledge $[6,50,63]$. It enables to combine the newly created and acquired knowledge with the available resources to implement business processes, functions, and activities, and improve organizational outcomes [52,55,64]. Knowledge application can be interpreted as implementing required knowledge in the organization's processes and activities to achieve knowledge strategy and sustainable organizational performance. The positive effect of organizational learning on knowledge application was verified by Wahda (2017) in the education sector in Indonesia [16], and by Turulja and Bajgorić (2018) in medium and large companies operating in Bosnia and Herzegovina [14]. These studies were limited to specific industries and geographic areas where the investigations were conducted. In order to prove the significant impact of organizational learning on the knowledge application process, the following hypothesis was formulated (Figure 1):

Hypothesis 1e (H1e). Organizational learning affects the knowledge application process positively.

The phenomenon of knowledge management practice has recently been recognized as a crucial factor in developing economies, such as the Middle East countries which are struggling with several geopolitical and economic constraints like poverty, growing population, corruption, unemployment, and limited entrepreneurship, in addition to the lack of strategic alliances [65]. These conditions make the knowledge management phenomenon less investigated, but necessary to explore in order to support the development of these countries and their evolution toward knowledge-based economies [38]. This study seeks to investigate the mediating role of knowledge management in the relationship between organizational learning and sustainable organizational performance in a knowledge-based sector as audit and consulting companies in the Middle East region.

Sustainability can be defined as a systematic approach to gain uniqueness and leadership through driving organizations toward better performance [66]. According to Athayde et al. (2017), sustainability is a developing approach that involves applying knowledge in organizations by creating an innovative learning environment and generating best practices through collective actions [67]. Akram et al. (2018) stated that organizations could attain sustainability by implementing efficient knowledge management and innovative practices. Based on the United Nations report, sustainable development meets the present's needs by maintaining the ability to meet future generations' needs [68]. Scientific research results have shown that business practitioners use knowledge management as one of the efficient tools to reach sustainability in the inner business processes and an unstable dynamic business environment [66]. Sustainability leads organizations to achieve higher performance by efficiently managing resources in business processes and operations $[69,70]$. Sustainability is a manifestation of a decrease in costs and an increase in revenues by applying innovative practices 
that improve the organization's competencies in order to achieve knowledge strategy, uniqueness, leadership, and fulfill its stakeholders' needs while providing value in the long term [69-71].

Sustainable organizational performance is the organizational performance that ensures the efficient usage of natural resources in a way that does not lead to losing economic opportunities in the future and does not cause any harm to society and the environment [72,73]. It involves incorporating environmental integrity, social equity, and economic prosperity in the organization's performance $[17,74]$. Given the increasing focus on sustainability, organizations are forced to reassess their performance based on interrelated sustainability measurements. In this situation, economic performance refers to the organization's financial position, social performance approaches to the management practices and the organization's responsibility towards its stakeholders, and environmental performance appeals to the organization's responsibility towards the environment [74]. Coutinho et al. (2018) recognized that sustainable organizational performance depends on an organization's strategies and practices, where sustainability principles affect the overall organization's performance [75]. As per Abbas (2020), the sustainable organizational performance aims to link the sustainability aspects to the organization's decision-making process and encourage the management to consider the impact of their decisions in the long term [17]. According to Lee and Ha-Brookshire (2018), organizations achieving a high level of sustainable organizational performance are more likely to fulfill the stakeholders' needs, and achieve better employees' productivity and higher competitive advantage [74]. The evolution of knowledge economies is an essential framework for global growth based on the three pillars of sustainability: economic, social, and environmental. Considering the importance of knowledge creation and intellectual capital in knowledge-based economies, organizations are required to create value, innovate, and grow in order to adjust to dynamic changes quickly. Therefore, organizations should reconsider their business development policies to incorporate knowledge economies' perceptions while maintaining sustainability [76].

Researchers who studied the relationship between knowledge management and sustainable organizational performance concluded that organizations could attain sustainable organizational performance by implementing efficient knowledge management processes and combining them with organizations' strategies and activities [17-20,77]. However, despite some previous studies concerning the knowledge management practice impact on sustainable organizational performance, there is still a gap of evidence on the influence of the whole knowledge management cycle, including five knowledge management processes on sustainable organizational performance. Scientists and business practitioners have analyzed knowledge management practice's impact on sustainable organizational performance through different knowledge management practice perspectives. Previous studies have also demonstrated a partially positive effect of knowledge management practice on a sustainable organizational performance in Pakistanis, Portuguese, and Mexican specific business sectors [17-20].

For instance, Abbas (2020) analyzed knowledge acquisition importance in the relationship between total quality management and corporate sustainability (environmental, social, and economic sustainability) in Pakistan manufacturing and services firms. Research results proved that knowledge acquisition has a positive impact on corporate environmental and economic sustainability. However, it was identified that knowledge management has a negative impact on corporate social sustainability [17]. According to López-Torres et al. (2019), the operationalization of knowledge management and sustainability in operations were analyzed through eleven constructs integrating knowledge acquisition associated with the learning and awareness necessary to prosper sustainability in operations. Research results verified that knowledge acquisition positively impacts sustainability in Mexican manufacturing small and medium-sized enterprises [18]. Shahzad et al. (2020) examined the role of knowledge acquisition for sustainable corporate performance integrating green innovation and organizational agility in Pakistan's multinational manufacturing corporations. The study revealed the positive effect of knowledge acquisition on sustainable corporate performance [20]. These studies showed some limitations related to the sectors analyzed and the geographic area where the studies were conducted. In order to test the positive impact 
of knowledge acquisition on sustainable organizational performance in audit and consulting companies in the Middle East region, the following hypothesis was formulated (Figure 1):

Hypothesis 2 (H2). Knowledge acquisition affects positively sustainable organizational performance.

Furthermore, the relationship between knowledge creation, total quality management, and corporate sustainability (environmental, social, and economic sustainability) in Pakistan's manufacturing and services firms was examined by Abbas (2020). Research results proved the positive impact of knowledge creation on corporate environmental and economic sustainability. However, it does not have the same effect on corporate social sustainability [17]. López-Torres et al. (2019) also analyzed the operationalization of knowledge management and sustainability in operations by integrating knowledge creation. The study was conducted in Mexican manufacturing small and medium-sized enterprises. Research results revealed that knowledge creation has a positive impact on sustainability in operations [18]. Previous researches had limitations related to the small generalizability of the findings. In order to verify the impact of knowledge creation on sustainable organizational performance in the Middle Easter audit and consulting companies, the following hypothesis was formed (Figure 1):

Hypothesis 3 (H3). Knowledge creation affects positively sustainable organizational performance.

According to Lin et al. (2016), knowledge retention has a negative influence on knowledge loss and, therefore, positively affects the analyzed departments' effectiveness in Taiwan [77]. A gap is found in previous studies related to the relationship between knowledge storage and sustainable organizational performance. In order to fulfill the deficiencies in previous studies, this research examined the effect of knowledge storage on sustainable organizational performance in an intensive knowledge-based sector, that of audit and consulting companies in the Middle East region. Accordingly, the following hypothesis was proposed (Figure 1):

Hypothesis 4 (H4). Knowledge storage affects positively sustainable organizational performance.

Abbas (2020) examined the importance of knowledge sharing in the relationship between total quality management and corporate sustainability (environmental, social, and economic sustainability) in Pakistan manufacturing and services firms. The study results verified that knowledge sharing had a positive impact on corporate environmental and economic sustainability, but not on corporate social sustainability [17]. Shahzad et al. (2020) analyzed the effect of knowledge dissemination on sustainable corporate performance by integrating green innovation and organizational agility. The study was conducted in the multinational manufacturing corporations of Pakistan. Research results demonstrated the positive effect of knowledge dissemination on sustainable corporate performance [20]. Based on research results conducted by Muñoz-Pascual et al. (2019), the knowledge sharing process within organizations and other stakeholders allowed Portuguese companies to achieve sustainable environmental, financial, and social goals [19]. Previous studies showed limitations in terms of the studied sectors and countries. In order to study the effect of knowledge sharing on sustainable organizational performance in the Middle Eastern audit and consulting companies, the following hypothesis was formulated (Figure 1):

Hypothesis 5 (H5). Knowledge sharing affects positively sustainable organizational performance.

The positive effect of knowledge application on sustainable organizational performance was previously demonstrated by Abbas (2020) in the manufacturing and services firms in Pakistan [17] and by Shahzad et al. (2020) in the multinational manufacturing corporations of Pakistan [20]. Those studies' results are limited to specific industries in Pakistan. In order to verify the impact of 
knowledge application on sustainable organizational performance in the intensive knowledge-based sector in the Middle East region, the following hypothesis was formed (Figure 1):

Hypothesis 6 (H6). Knowledge application affects positively sustainable organizational performance.

The relationship between organizational learning and sustainable performance was studied by Bilan et al. (2020) in Malaysian manufacturing organizations [78] and by Hutomo et al. (2018) in Indonesia and Malaysia Fishery Industries [79]. The researches' results revealed a positive effect of organizational learning on sustainable performance.

As a result of previous research limitations related to the small generalizability of the findings (e.g., individual countries and business sectors as manufacturing), the current study focused on the intensive knowledge-based sector of audit and consulting companies in the Middle East region to examine the whole knowledge management cycle and to find out organizational learning's impact on sustainable organizational performance through knowledge management processes by focusing on sustainability aspects. Accordingly, the following hypothesis was proposed (Figure 1):

Hypothesis 7 (H7). Organizational learning affects positively sustainable organizational performance.

In order to illustrate the relationships between the research variables, the following research model was formed (Figure 1).

\section{Research Methodology}

Since the audit and consulting sector is a part of the knowledge-based industry, organizational learning is recognized as the main factor in the efficient implementation of knowledge management processes [80]. Besides, audit and consulting services need to integrate organizational learning as the main component of their culture in order to achieve the desired sustainable organizational performance. "To stay ahead, we invest in people"; this statement, for instance, manifests the organizational learning strategy at Deloitte (one of the Big Four audit and consulting companies in the world), where the learning and growth curriculum goes above and beyond earning professional designations and certifications. They invest in learning and growth opportunities for all members, leading to considerable impact, thriving in a dynamic culture of inclusion, collaboration, and high performance.

Accordingly, this research is designed as an empirical study to test the relationship between the variables. The research is divided into three parts: in the first part, the independent variable is characterized by the organizational learning, and the dependent variables are characterized by the knowledge management processes (knowledge acquisition, creation, storage, sharing, and application), while in the second part the five knowledge management processes represent the independent variables, and the sustainable organizational performance represents the dependent variable. Then the effect of organizational learning on sustainable organizational performance is addressed, where organizational learning represents the independent variable, and sustainable organizational performance represents the dependent variable.

Data was collected using a research survey distributed among Certified Public Accountants (CPAs), owners, senior managers, and team leaders in local audit and consulting companies to test the research hypotheses. CPAs, members of accounting and auditing associations, earn the licensed experts' status after passing four exams related to the profession and to a general business environment and satisfying a minimum of two years of professional experience under the supervision of a licensed CPA, who shares professional competencies (knowledge, abilities, and skills) during this supervision period. CPAs primary responsibilities are to assess all types of accounts and to state assumptions on the financial statements. These opinions become the basis for decision-making and future planning for organizations. As members of the associations, CPAs are committed to lifelong professional learning to empower them to increase their professional competencies through the whole knowledge management cycle. CPAs have to follow professional development by attending specialized workshops organized 
by their companies or participating with international or local, public or private academic, financial, or economic bodies and institutes. Accordingly, they can maintain their licenses, as per the laws of the related associations.

The study was conducted between April 2018 and April 2019, when the total number of CPAs in Lebanon, Syria, and Jordan was around 4300, as per the related associations' databases. Among the contacted experts, 378 responded and filled up the questionnaire, constituting an acceptable sample size at a confidence level of $95 \%$ as per the Robustness test. The study involved males $(72.2 \%)$ and females $(27.8 \%)$, age $\geq 25$ and $<35(45.5 \%)$ and $\geq 35$ and $<45(21.2 \%)$, master's holders $(38.6 \%)$ and certified public accountants (CPAs) (31.2\%), upper managers (30.4\%), and senior operators $(26.5 \%)$, operating in local (73.3\%) and multinational companies (26.7\%) (Table 1).

Table 1. Demographic description of the survey participants.

\begin{tabular}{ccc}
\hline Category & Frequency & Percentage (\%) \\
\hline$<25$ & Age & $4.8 \%$ \\
$\geq 25$ and $<35$ & 18 & $45.5 \%$ \\
$\geq 35$ and $<45$ & 172 & $21.2 \%$ \\
$\geq 45$ & 108 & $28.6 \%$ \\
Male & Gender & $72.2 \%$ \\
Female & 273 & $27.8 \%$ \\
& 105 & \\
Bachelor & Education & $29.9 \%$ \\
Master & 113 & $38.6 \%$ \\
Certified public & 146 & $31.2 \%$ \\
accountant (CPA) & 118 & $0.3 \%$ \\
Other & 1 & \\
& Job position & $21.4 \%$ \\
Junior level & 81 & $21.7 \%$ \\
Middle level & 82 & $26.5 \%$ \\
Senior level & 100 & $30.4 \%$ \\
Upper management & 115 & $73.3 \%$ \\
Local & Type of organization & $26.7 \%$ \\
Multinational & 101 & \\
\hline & &
\end{tabular}

The data collection and analysis represent a field study where respondents answered all survey questions based on a five-point Likert-scale developed to measure respondents' attitudes directly and to range from " 1 " meaning "Strongly disagree", to " 5 " meaning "Strongly agree". The Likert-scale assumes that an attitude's strength is linear and assumes that attitudes under investigation could be measured through numerical value.

The constructs used to assess the different indicators were obtained from previous scientific studies, providing a valued data collection source where their reliability and validity were previously tested and verified. The organizational learning factor was assessed through different indicators, such as encouraging employees to attend training sessions to acquire new knowledge and share their knowledge, considering learning as an investment for knowledge creation. Indeed, encouraging employees to store their professional knowledge and experience and continue their education will benefit the organization [81-83]. The knowledge acquisition process constructs include acquiring knowledge for developing specific programs, expertise, and intelligence $[41,81]$. The knowledge creation process constructs consist of the generation of best practices to improve future projects and exploit new opportunities to serve the clients and deliver the new services based on market demands $[41,81,84,85]$. The knowledge storage process constructs incorporate the customer's database and knowledge database that is easy to access $[7,81,84,86]$. The knowledge sharing process constructs combine knowledge 
sharing with colleagues, stakeholders, and business units [41,51,81-83,87]. The knowledge application process constructs cover the conversion of knowledge to action plans, match knowledge sources to problem-solving, and the efficient application of knowledge to reach specific goals $[7,41,81-84,87]$. The sustainable organizational performance was assessed through the high quality of services provided, the adoption of new services opportunities, the effectiveness of the services delivered, the quick adaptation to unanticipated changes, the competition in the market, and the profitability leading to the sustainability of the organization's performance $[81,86]$.

The techniques applied to test the research hypotheses were the structural equation modeling (SEM) techniques, which include various models' types to describe relationships among constructs and provide a quantitative analysis of a hypothesized research model. The software used to generate the results and conduct the analysis in this research are Statistical Package for social science (SPSS) and Stata software for statistics and data science.

\section{Research Results and Discussion}

The descriptive statistics provide the mean and standard deviation for each construct of knowledge acquisition, knowledge creation, knowledge storage, knowledge sharing, and knowledge application, in addition to organizational learning factor and sustainable organizational performance. Three levels were identified based on the results of the responses. When the mean is higher than or equal to 3.75, a high agreement of the respondents is recognized. When the mean is higher than 2.75 and lower than 3.75 , then a medium agreement of the respondents is recognized and, when the mean is lower than 2.75 , a low agreement is recognized.

The organizational learning contribution to knowledge management processes results in the following mean values: encouraging employees to continue their education for the benefit of the organization and to store the learning they earn (4.23), encouraging employees to attend training sessions to acquire new knowledge (4.21), considering employees learning as an investment in knowledge creation (4.04), having training processes for employees to share knowledge (3.77). The results are higher than 3.75, meaning that respondents highly agreed with these statements and mostly agree with the relation of organizational learning with knowledge storage and application (Table 2).

Table 2. Descriptive statistics of the indicators.

\begin{tabular}{cccc}
\hline Variable & Mean & $\begin{array}{c}\text { Standard } \\
\text { Deviation }\end{array}$ & $\begin{array}{c}\text { Factor } \\
\text { Loadings }\end{array}$ \\
\hline $\begin{array}{c}\text { Organizational learning } \\
\text { Our organization encourages employees to attend training } \\
\text { sessions to acquire new knowledge }\end{array}$ & 4.21 & 0.95 & 0.96 \\
\hline $\begin{array}{c}\text { Our organization considers employees learning as an } \\
\text { investment in knowledge creation }\end{array}$ & 4.04 & 0.94 & 0.79 \\
\hline $\begin{array}{c}\text { Our organization encourages employees to store the learning } \\
\text { they earn }\end{array}$ & 4.23 & 0.86 & 0.9 \\
\hline $\begin{array}{c}\text { Our organization has broad training processes where employees } \\
\text { can share knowledge }\end{array}$ & 3.77 & 1.12 & 0.8 \\
\hline $\begin{array}{c}\text { Our organization encourages employees to continue their } \\
\text { education, which will be a benefit to the organization }\end{array}$ & 4.23 & 0.81 & 0.89 \\
\hline Knowledge acquisition \\
specific programs
\end{tabular}


Table 2. Cont.

\begin{tabular}{|c|c|c|c|}
\hline Variable & Mean & $\begin{array}{l}\text { Standard } \\
\text { Deviation }\end{array}$ & $\begin{array}{l}\text { Factor } \\
\text { Loadings }\end{array}$ \\
\hline \multicolumn{4}{|l|}{ Knowledge creation } \\
\hline $\begin{array}{l}\text { Generating best practices from previous projects to improve } \\
\text { future projects }\end{array}$ & 3.87 & 0.8 & 0.82 \\
\hline Using new opportunities to serve our clients & 4.06 & 0.73 & 0.8 \\
\hline Providing new services depending on the market demands & 3.85 & 0.82 & 0.81 \\
\hline \multicolumn{4}{|l|}{ Knowledge storage } \\
\hline Keeping a customer information database that is easy to access & 4.07 & 0.82 & 0.8 \\
\hline Having a knowledge database that is easy to access & 4.03 & 0.89 & 0.81 \\
\hline \multicolumn{4}{|l|}{ Knowledge sharing } \\
\hline $\begin{array}{l}\text { Sharing with our colleagues the knowledge necessary for } \\
\text { projects on hand }\end{array}$ & 4.2 & 0.77 & 0.6 \\
\hline Sharing knowledge with the stakeholders & 3.78 & 1.05 & 0.85 \\
\hline $\begin{array}{l}\text { Having the capability to share relevant knowledge among } \\
\text { business units }\end{array}$ & 4.06 & 0.72 & 0.9 \\
\hline \multicolumn{4}{|l|}{ Knowledge application } \\
\hline Having processes for converting knowledge into action plans & 3.89 & 0.9 & 0.6 \\
\hline $\begin{array}{l}\text { Having processes for matching sources of knowledge to } \\
\text { problem-solving }\end{array}$ & 4.12 & 0.73 & 0.78 \\
\hline Applying knowledge efficiently to reach our goals & 4.1 & 0.66 & 0.78 \\
\hline \multicolumn{4}{|l|}{ Sustainable organizational performance } \\
\hline The organization provides high-quality services & 4.33 & 0.61 & 0.63 \\
\hline The organization can adopt new services opportunities & 4.25 & 0.72 & 0.7 \\
\hline $\begin{array}{c}\text { The organization performs well in improving the effectiveness } \\
\text { of services delivered }\end{array}$ & 4.12 & 0.88 & 0.81 \\
\hline The organization adapts quickly to unanticipated changes & 4.06 & 0.76 & 0.78 \\
\hline The organization can compete in the current market & 4.23 & 0.6 & 0.87 \\
\hline The organization is considered profitable in the industry & 4.03 & 0.69 & 0.6 \\
\hline
\end{tabular}

The highest mean values of responses on the indicators of the five knowledge management processes were recognized as follows: the knowledge sharing with colleagues for projects on hand (4.20), the knowledge application to problem-solving (4.12), the knowledge storage in customer database that is easy to access (4.07), the knowledge creation through the use of new opportunities to serve clients (4.06), and the knowledge acquisition for developing specific programs (3.87) (Table 2). Besides, respondents highly agreed to the indicators of sustainable organizational performance such as the high quality of services provided (4.33), the adoption of new service opportunities (4.25), the competition in the current market (4.23), the effectiveness of the services delivered (4.12), the quick adaptation to unanticipated changes (4.06), and the profitability (4.04) (Table 2).

The knowledge management processes-including knowledge acquisition, creation, storage, sharing, and application-organizational learning and sustainable organizational performance factors were assessed using factor analysis. The constructs with factor loadings of less than 0.60 were eliminated, and all remaining constructs in the study have factor loadings greater than or equal to the threshold of 0.6 (Table 2).

An analysis was conducted to identify how the effect of organizational learning on knowledge management processes and sustainable organizational performance differs between local and 
multinational audit and consulting companies in the Middle East. Among the respondents, 277 experts represent local companies, and 101 experts represent multinational companies such as the Big Four (Deloitte, PWC, EY, and KPMG). The fact that the number of respondents from local companies exceeded the multinational companies is associated with the limited number of multinational audit and consulting companies in the Middle East countries. The research focuses on integrating organizational learning in both types of companies to support the five knowledge management processes (acquisition, creation, storage, sharing, and application) and sustainable organizational performance. The comparison of means, standard deviation, and the independent samples $t$-test were performed in order to analyze the difference between local and multinational companies (Table 3).

Table 3. Organizational learning supporting knowledge management processes and sustainable organizational performance in local and multinational audit and consulting companies.

\begin{tabular}{|c|c|c|c|c|c|c|c|}
\hline $\begin{array}{c}\text { Knowledge } \\
\text { Management } \\
\text { Processes/Type of } \\
\text { Company }\end{array}$ & Indicators & Acquisition & Creation & Storage & Sharing & Application & $\begin{array}{c}\text { Sustainable } \\
\text { Organizational } \\
\text { Performance }\end{array}$ \\
\hline \multirow{2}{*}{ Local companies } & Mean & 4.05 & 3.86 & 4.13 & 3.48 & 4.10 & 3.93 \\
\hline & $\mathrm{SD}^{*}$ & 1.02 & 0.99 & 0.94 & 1.10 & 0.85 & 0.86 \\
\hline $\begin{array}{l}\text { Multinational } \\
\text { companies }\end{array}$ & Mean & 4.64 & 4.55 & 4.50 & 4.54 & 4.57 & 4.56 \\
\hline \multirow[t]{2}{*}{$t$-test results } & $\mathrm{df}^{* *}$ & 353.16 & 321.20 & 325.92 & 268.76 & 264.36 & 240.69 \\
\hline & $p$ & $<0.05$ & $<0.05$ & $<0.05$ & $<0.05$ & $<0.05$ & $<0.05$ \\
\hline
\end{tabular}

Note: $\mathrm{SD}^{*}$ - Standard Deviation; $\mathrm{df}^{* *}$ — degree of freedom.

The independent samples $t$-test results revealed greater means for multinational companies than in local companies, indicating the support of organizational learning for knowledge acquisition (4.64 in multinational $>4.05$ in local), knowledge creation ( 4.55 in multinational $>3.86$ in local), knowledge storage ( 4.50 in multinational $>4.13$ in local), knowledge sharing (4.54 in multinational $>3.48$ in local), and knowledge application (4.57 in multinational $>4.10$ in local). Experts also agreed that organizational learning supports sustainable organizational performance (4.56 in multinational $>3.93$ in local). All $t$-values with a positive degree of freedom result in $p$-values of less than 0.05 , demonstrating that the means differences between local and multinational audit and consulting companies are statistically significant (Table 3). The designated results could be associated with the shortage of local companies' resources in the Middle East being the case of all developing countries. Experts operating in multinational audit and consulting companies are granted the opportunity to attend workshops and training sessions in order to know the latest trends and techniques in the professional area and gain new knowledge outsourced from the most developed countries, which is not affordable in the case of local companies in the Middle East.

The reliability of the survey constructs and the internal consistency between the indicators of each variable were assessed through Cronbach's alpha coefficient. The value of the Cronbach's alpha coefficient ranges from 0 to 1 , with the acceptable value being 0.7 [2,32,51]. The indicators under the five knowledge management processes (knowledge acquisition, creation, storage, sharing, and application), the whole knowledge management cycle, the organizational learning factor as well as the sustainable organizational performance indicators demonstrated very good internal consistency with each other with a Cronbach alpha value ranging between 0.757 and 0.931 , indicating high reliability of the constructs (Table 4).

Subsequently, the validity of the survey constructs was tested through the Average Variance Extracted (AVE). The constructs' results demonstrate a good validity with AVE ranging between 0.52 and 0.84 , higher than the threshold of 0.5 (Table 4). Besides, Harman's single factor test was applied to identify common method variance and detect any common variance bias. The percentage of variance determined was $41.32 \%$ less than $50 \%$, indicating no common variance problem in this study. 
Table 4. Reliability and validity results.

\begin{tabular}{ccc}
\hline Variable & Cronbach's Alpha & Average Variance Extracted (AVE) \\
\hline Organizational learning & 0.931 & 0.84 \\
Knowledge acquisition & 0.890 & 0.58 \\
Knowledge creation & 0.833 & 0.64 \\
Knowledge storage & 0.757 & 0.52 \\
Knowledge sharing & 0.869 & 0.71 \\
Knowledge application & 0.858 & 0.74 \\
Knowledge management cycle & 0.734 & 0.63 \\
Sustainable organizational performance & 0.836 & 0.54 \\
\hline
\end{tabular}

The model's goodness of fit was measured through the indices (Table 5). The Chi-square values with a positive degree of freedom have a $p$-value of less than 0.01. The Root Mean Square Error (RMSE) is less than the threshold of 0.08 for organizational learning, knowledge management processes (knowledge acquisition, creation, storage, sharing, and application), the whole knowledge management cycle, and sustainable organizational performance constructs. These results demonstrate the statistical significance of the model (Table 5).

Table 5. The goodness of fit indices.

\begin{tabular}{ccccc}
\hline Construct/Indices & Chi-Square & $\boldsymbol{p}$-Value & $\begin{array}{c}\text { Degree of } \\
\text { Freedom (df) }\end{array}$ & $\begin{array}{c}\text { Root Mean Square } \\
\text { Error (RMSE) }\end{array}$ \\
\hline Organizational learning & 260.07 & $<0.01$ & 13 & 0.043 \\
Knowledge acquisition & 97.93 & $<0.01$ & 9 & 0.042 \\
Knowledge creation & 399.62 & $<0.01$ & 9 & 0.035 \\
Knowledge storage & 154.05 & $<0.01$ & 8 & 0.035 \\
Knowledge sharing & 450.25 & $<0.01$ & 9 & 0.039 \\
Knowledge application & 364.95 & $<0.01$ & 8 & 0.035 \\
Knowledge management cycle & 318.55 & $<0.01$ & 43 & 0.031 \\
Sustainable organizational performance & 201.84 & $<0.01$ & 12 & 0.029 \\
\hline
\end{tabular}

$R^{2}$ and adjusted $R^{2}$ values of the sustainable organizational performance and the five knowledge management processes as dependent variables were generated in order to assess the structural model's quality. $R^{2}$ ranges between 0 and 1 , where a higher value determines the model's better capability [88]. Three values are recognized as the criteria for $\mathrm{R}^{2}$ where $0.19,0.33$, and 0.67 represent a low, average, and high value, respectively [89]. $R^{2}$ of the studied variables (knowledge acquisition, knowledge creation, knowledge sharing, knowledge application, and sustainable organizational performance) ranges between 0.265 and 0.446 , resulting in an average $R^{2}$. However, the $R^{2}$ of the knowledge storage scores a low value of 0.161 . The results demonstrate acceptable proposed model paths (Table 6).

The correlation of organizational learning and sustainable organizational performance with the five knowledge management processes (knowledge acquisition, creation, storage, sharing, and application), and the correlation of organizational learning with sustainable organizational performance were performed in order to define a relationship between variables. All correlation coefficients are positive, indicating the positive association of the organizational learning with the five knowledge management processes and the sustainable organizational performance, in addition to the positive association of the five knowledge management processes with the sustainable organizational performance (Table 7). The $p$ values of less than 0.01 prove the significance of the correlation coefficients.

A structural equation modeling technique was applied to test the proposed hypotheses. The results reveal that the five knowledge management processes (knowledge acquisition, creation, storage, sharing, and application) were positively and significantly associated with sustainable organizational performance at a $p$-value of less than 0.05 . Accordingly, $\mathrm{H} 2, \mathrm{H} 3, \mathrm{H} 4, \mathrm{H} 5$, and $\mathrm{H} 6$ hypotheses were supported (Table 8). These results were generated from an intensive knowledge-based sector as audit and consulting. Similar studies were conducted in Pakistan manufacturing and services firms, 
Mexican manufacturing SMEs, and Portuguese companies where a positive relationship between the studied knowledge management processes and sustainable organizational performance was recognized except for social sustainability in Pakistan [17-20].

Table 6. $R^{2}$ and adjusted $R^{2}$ values.

\begin{tabular}{ccc}
\hline Variable & $\mathbf{R}^{\mathbf{2}}$ & Adjusted $\mathbf{R}^{\mathbf{2}}$ \\
\hline Knowledge acquisition & 0.446 & 0.445 \\
Knowledge creation & 0.312 & 0.310 \\
Knowledge storage & 0.161 & 0.159 \\
Knowledge sharing & 0.265 & 0.263 \\
Knowledge application & 0.424 & 0.422 \\
Sustainable organizational performance & 0.373 & 0.365 \\
\hline
\end{tabular}

Table 7. Pearson correlation of organizational learning and sustainable organizational performance with the five knowledge management processes.

\begin{tabular}{cccccc}
\hline Construct/Process & Acquisition & Creation & Storage & Sharing & $\begin{array}{c}\text { Sustainable } \\
\text { Application } \\
\text { Organizational } \\
\text { Performance }\end{array}$ \\
\hline $\begin{array}{c}\text { Organizational learning } \\
\text { Sustainable organizational } \\
\text { performance }\end{array}$ & $0.668^{* *}$ & $0.559^{* *}$ & $0.402^{* *}$ & $0.515^{* *}$ & $0.651^{* *}$ \\
\hline & $0.549^{* *}$ & $0.537^{* *}$ & $0.365^{* *}$ & $0.436^{* *}$ & $0.488^{* *}$ \\
& $* *$ Correlation is significant at the 0.01 level $(p<0.01)$.
\end{tabular}

Table 8. Structural equation modeling with the research paths.

\begin{tabular}{ccccc}
\hline $\begin{array}{c}\text { Research } \\
\text { Hypothesis }\end{array}$ & $\begin{array}{c}\text { Standardized } \\
\text { Coefficient }\end{array}$ & $\boldsymbol{t}$-Value & $\boldsymbol{p}$-Value & $\begin{array}{c}\text { Empirical } \\
\text { Evidence }\end{array}$ \\
\hline $\mathrm{H} 1 \mathrm{a}$ & 0.404 & 13.15 & 0.019 & Supported \\
$\mathrm{H} 1 \mathrm{~b}$ & 0.535 & 7.48 & 0.053 & Not supported \\
$\mathrm{H} 1 \mathrm{c}$ & 0.250 & 6.46 & 0.024 & Supported \\
$\mathrm{H} 1 \mathrm{~d}$ & 0.304 & 9.65 & 0.002 & Supported \\
$\mathrm{H} 1 \mathrm{e}$ & 0.455 & 12.58 & $<0.001$ & Supported \\
$\mathrm{H} 2$ & 0.327 & 13.15 & $<0.001$ & Supported \\
$\mathrm{H} 3$ & 0.369 & 12.12 & $<0.001$ & Supported \\
$\mathrm{H} 4$ & 0.251 & 7.51 & $<0.001$ & Supported \\
$\mathrm{H} 5$ & 0.265 & 9.17 & $<0.001$ & Supported \\
$\mathrm{H} 6$ & 0.387 & 12.98 & $<0.001$ & Supported \\
$\mathrm{H} 7$ & 0.358 & 7.43 & $<0.001$ & Supported \\
\hline
\end{tabular}

Organizational learning is positively associated with knowledge acquisition, knowledge storage, knowledge sharing, and knowledge application with a $p$-value of less than 0.05 . Accordingly, the hypotheses H1a, H1c, H1d, and H1e were supported. However, hypothesis H1b, organizational learning association with knowledge creation, was not supported, with a $p$-value of 0.053 greater than 0.05. Besides, organizational learning's positive effect on sustainable organizational performance, H7, was supported (Table 8). In an intensive knowledge-based sector such as audit and consulting, organizational learning is considered as a support for the knowledge management practice and the companies' operations. Other previously studied sectors such as the education sector in Indonesia, and medium and large companies in Bosnia and Herzegovina, manufacturing organizations in Indonesia and Malaysia, and Malaysian Fishery Industries, revealed similar results [14,16,78,79].

The structural equation modeling results indicate that the organizational learning practice in the audit and consulting companies mainly operating in the Middle East region positively affects the efficiency of the knowledge acquisition, storage, sharing, and application processes. However, it does not have the same impact on the knowledge creation process, with $\mathrm{H} 1 \mathrm{~b}$ being rejected, indicating that organizational learning is not considered as an investment in knowledge creation for the Middle Eastern 
audit and consulting companies, and proving the inability of these companies to generate best practices for future improvements, to use new opportunities for better customer services, and to provide new services in the market. This could be associated with the peculiarities of the economy and business environment where these companies are operating (developing countries) and the shortage in available resources that would allow them to invest in organizational learning to support knowledge creation. However, the study results show that these companies' employees have comprehensive training sessions to share their knowledge. Additionally, employees are encouraged to attend training sessions to acquire new knowledge, store their professional knowledge and experience, and continue their education, which will benefit the organization and positively affect sustainable organizational performance.

The research results are essential for evolving the knowledge-based sector in developing countries such as the Middle East region, specifically the audit and consulting companies. The Middle East countries facing massive economic and geopolitical constraints should pay considerable attention to knowledge management implementation to achieve sustainable organizational performance. Moreover, organizations should consider organizational learning as an essential aspect of their corporate culture affecting the efficient implementation of knowledge management processes concerning the organization's performance.

The Sobel test was conducted in order to verify the significance of the mediating effect of the five knowledge management processes (knowledge acquisition, creation, storage, sharing, and application), in addition to the mediating effect of the whole knowledge management cycle, between organizational learning and sustainable organizational performance in the Middle Eastern audit and consulting companies (Table 9).

Table 9. The Sobel test statistic.

\begin{tabular}{ccc}
\hline Mediator & Sobel Test Statistic & $p$-Value \\
\hline Knowledge acquisition & 10.208 & $<0.01$ \\
Knowledge creation & 8.915 & $<0.01$ \\
Knowledge storage & 5.663 & $<0.01$ \\
Knowledge sharing & 7.324 & $<0.01$ \\
Knowledge application & 9.042 & $<0.01$ \\
Knowledge management cycle & 11.078 & $<0.01$ \\
\hline
\end{tabular}

The Sobel test results proved that each of the knowledge management processes (knowledge acquisition, creation, storage, sharing, and application) and the knowledge management cycle including the five processes have a significant mediating role between organizational learning and sustainable organizational performance in the Middle Eastern audit and consulting companies with $p$-values of less than 0.01 .

\section{Conclusions}

In transforming an information society into a knowledge society, organizational learning is considered an essential factor. It influences the development of the individuals' competencies (knowledge, abilities, and skills) through the knowledge management practice, which leads to achieving the organization's knowledge strategy, creating value between the organization and customers, and improving sustainable organizational performance.

This research is designed to examine the impact of organizational learning on knowledge management processes, including knowledge acquisition, creation, storage, sharing, and application and the effect of these processes and the organizational learning on the sustainable organizational performance in the Middle Eastern audit and consulting companies. Since organizational learning tends to foster, create, and apply new knowledge, it is supposed to highlight the necessity of building a sustainable knowledge management cycle within the organization. 
The data required for analysis in this research was collected by using a structured questionnaire (expert evaluation), and structural equation modeling techniques were used to test the research hypotheses. The results have proven the positive influence of organizational learning on sustainable organizational performance and knowledge management processes-knowledge acquisition, storage, sharing, and application. However, the impact seems less significant in the Middle Eastern audit and consulting companies' knowledge creation, revealing the fact that developing economies such as those of Middle East countries cannot afford the needed resources to invest in organizational learning for the creation of new knowledge, demonstrating the analysis of the difference between local and multinational companies in this region as well. As a result, there is a lack of the generation of best practices from previous projects, and the delivery of new services is needed in the global market. The results have also proven the positive and significant influence of the five knowledge management processes on sustainable organizational performance while considering its economic aspects. Furthermore, the research demonstrated the significant mediating role of knowledge management processes between organizational learning and sustainable organizational performance.

This research has practical implications on the knowledge-based sector in developing countries such as the Middle East, where knowledge management practices could contribute to developing the organizations operating in this sector and improving their performance. According to these study results, knowledge-based industries are recommended to encourage organizational learning in order to develop the employees' competencies (knowledge, abilities, and skills) for implementing knowledge management practices and maintaining sustainable organizational performance.

This study's limitations include the fact that the structured questionnaire (expert evaluation) was conducted in a particular geographical area and specific knowledge-based industry, since the survey was performed in the Middle Eastern audit and consulting sector, limiting the generalization of the results. Future research areas could examine other knowledge-based sectors in different geographical regions with a common cultural and economic background.

Author Contributions: Conceptualization, J.R., M.K., and I.M.-K.; methodology, J.R. and M.K.; data collection and formal analysis, M.K.; writing_original draft preparation, J.R. and M.K.; final review and editing, I.M.-K.; visualization, J.R.; supervision, J.R.; funding acquisition, I.M.-K. All authors have read and agreed to the published version of the manuscript.

Funding: This research was partially funded by the Portuguese Foundation for Science and Technology, Grant Agreement Number UIDB/00315/2020.

Conflicts of Interest: The authors declare no conflict of interest.

\section{References}

1. Tubigi, M.; Alshawi, S. The Impact of Knowledge Management Processes on Organisational Performance: The Case of the Airline Industry. J. Enterp. Inf. Manag. 2015, 28, 167-185. [CrossRef]

2. Akbari, N.; Ghaffari, A. Verifying relationship of knowledge management initiatives and the empowerment of human resources. J. Knowl. Manag. 2017, 21. [CrossRef]

3. Li, J.; Herd, A. Shifting Practices in Digital Workplace Learning: An Integrated Approach to Learning, Knowledge Management, and Knowledge Sharing. Hum. Resour. Dev. Int. 2017, 20, 185-193. [CrossRef]

4. Consoli, D.; Elche, D. The evolving knowledge base of professional service sectors. J. Evol. Econ. 2012, 23, 477-501. [CrossRef]

5. Zheng, S.; Zhang, W.; Du, J. Knowledge-based dynamic capabilities and innovation in networked environments. J. Knowl. Manag. 2011, 15, 1035-1051. [CrossRef]

6. Chang, C.L.-H.; Lin, T.-C. The role of organizational culture in the knowledge management process. J. Knowl. Manag. 2015, 19, 433-455. [CrossRef]

7. Wu, I.-L.; Chen, J.-L. Knowledge management driven firm performance: The roles of business process capabilities and organizational learning. J. Knowl. Manag. 2014, 18, 1141-1164. [CrossRef]

8. Kianto, A.; Vanhala, M.; Heilmann, P. The impact of knowledge management on job satisfaction. J. Knowl. Manag. 2016, 20, 621-636. [CrossRef] 
9. Raudeliūnienė, J.; Tvaronavičienė, M.; Blažytė, M. Knowledge Management Practice in General Education Schools as a Tool for Sustainable Development. Sustainability 2020, 12, 4034. [CrossRef]

10. Imran, M.K.; Ilyas, M.; Aslam, U. Organizational learning through transformational leadership. Learn. Organ. 2016, 23, 232-248. [CrossRef]

11. El-Awad, Z. From Individuals to the Organization: A Transactive Memory System Perspective on Multilevel Entrepreneurial Learning. Learn. Organ. 2019, 26, 617-630. [CrossRef]

12. Oh, S.-Y.; Han, H.-S. Facilitating organisational learning activities: Types of organisational culture and their influence on organisational learning and performance. Knowl. Manag. Res. Pr. 2018, 18, 1-15. [CrossRef]

13. Ghasemzadeh, P.; Nazari, J.A.; Farzaneh, M.; Mehralian, G. Moderating role of innovation culture in the relationship between organizational learning and innovation performance. Learn. Organ. 2019, 26, 289-303. [CrossRef]

14. Turulja, L.; Bajgorić, N. Knowing Means Existing: Organizational Learning Dimensions and Knowledge Management Capability. Bus. Syst. Res. 2018, 9, 1-18. [CrossRef]

15. Liu, C.-H.S. Examining social capital, organizational learning and knowledge transfer in cultural and creative industries of practice. Tour. Manag. 2018, 64, 258-270. [CrossRef]

16. Wahda, W. Mediating Effect of Knowledge Management on Organizational Learning Culture in the Context of Organizational Performance. J. Manag. Dev. 2017, 36, 846-858. [CrossRef]

17. Abbas, J. Impact of total quality management on corporate sustainability through the mediating effect of knowledge management. J. Clean. Prod. 2020, 244, 118806. [CrossRef]

18. López-Torres, G.C.; Garza-Reyes, J.A.; Maldonado-Guzmán, G.; Kumar, V.; Rocha-Lona, L.; Cherrafi, A. Knowledge management for sustainability in operations. Prod. Plan. Control. 2019, 30, 813-826. [CrossRef]

19. Muñoz-Pascual, L.; Galende, J.; Curado, C. Human Resource Management Contributions to Knowledge Sharing for a Sustainability-Oriented Performance: A Mixed Methods Approach. Sustainability 2019, 12, 161. [CrossRef]

20. Shahzad, M.; Qu, Y.; Zafar, A.U.; Rehman, S.U.; Islam, T. Exploring the influence of knowledge management process on corporate sustainable performance through green innovation. J. Knowl. Manag. 2020, 24, 2079-2106. [CrossRef]

21. Souza, C.P.D.S.; Takahashi, A.R.W. Dynamic capabilities, organizational learning and ambidexterity in a higher education institution. Learn. Organ. 2019, 26, 397-411. [CrossRef]

22. Chou, S.Y.; Ramser, C.A. Multilevel Model of Organizational Learning: Incorporating Employee Spontaneous Workplace Behaviors, Leadership Capital and Knowledge Management. Learn. Organ. 2019, 26, 132-145. [CrossRef]

23. Engström, A.; Käkelä, N. Early Steps in Learning about Organizational Learning in Customization Settings: A Communication Perspective. Learn. Organ. 2019, 26, 27-43. [CrossRef]

24. Muniz, J. Organizational learning in Asia-Issues and challenges. Learn. Organ. 2019, 26, 117-122. [CrossRef]

25. Brix, J. Ambidexterity and organizational learning: Revisiting and reconnecting the literatures. Learn. Organ. 2019, 26, 337-351. [CrossRef]

26. Fiol, C.M.; Lyles, M.A. Organizational Learning. Acad. Manag. Rev. 1985, 10, 803-813. [CrossRef]

27. Tran, H.Q.; Pham, N.T.B. Organizational Learning as a Moderator of the Effect of Employee Participation on Academic Results: An Empirical Study in Vietnam. Learn. Organ. 2019, 26, 146-159. [CrossRef]

28. Kump, B.; Moskaliuk, J.; Cress, U.; Kimmerle, J. Cognitive foundations of organizational learning: Re-introducing the distinction between declarative and non-declarative knowledge. Front. Psychol. 2015, 6, 1-12. [CrossRef]

29. Acar, M.F.; Tarim, M.; Zaim, H.; Zaim, S.; Delen, D. Knowledge management and ERP: Complementary or contradictory? Int. J. Inf. Manag. 2017, 37, 703-712. [CrossRef]

30. Mirzaie, M.; Javanmard, H.-A.; Hasankhani, M.R. Impact of knowledge management process on human capital improvement in Islamic Consultative Assembly. Knowl. Manag. Res. Pr. 2019, 17, 316-327. [CrossRef]

31. Shahzad, K.; Bajwa, S.U.; Siddiqi, A.F.I.S.; Ahmid, F.; Sultani, A.R. Integrating Knowledge Management (KM) Strategies and Processes to Enhance Organizational Creativity and Performance: An Empirical Investigation. J. Model. Manag. 2016, 11, 154-179. [CrossRef]

32. Mahdi, O.R.; Nassar, I.A.; Almsafir, M.K. Knowledge management processes and sustainable competitive advantage: An empirical examination in private universities. J. Bus. Res. 2019, 94, 320-334. [CrossRef] 
33. Archer-Brown, C.; Kietzmann, J. Strategic knowledge management and enterprise social media. J. Knowl. Manag. 2018, 22, 1288-1309. [CrossRef]

34. Bloodgood, J.M. Knowledge acquisition and firm competitiveness: The role of complements and knowledge source. J. Knowl. Manag. 2019, 23, 46-66. [CrossRef]

35. Hashemi, P.; Khadivar, A.; Shamizanjani, M. Developing a domain ontology for knowledge management technologies. Online Inf. Rev. 2018, 42, 28-44. [CrossRef]

36. Muthuveloo, R.; Shanmugam, N.; Teoh, A.P. The impact of tacit knowledge management on organizational performance: Evidence from Malaysia. Asia Pac. Manag. Rev. 2017, 22, 192-201. [CrossRef]

37. Acharya, A.; Mishra, B. Exploring the relationship between organizational structure and knowledge retention: A study of the Indian infrastructure consulting sector. J. Knowl. Manag. 2017, 21, 961-985. [CrossRef]

38. Alshamsi, O.; Ajmal, M. Critical factors for knowledge sharing in technology-intensive organizations: Evidence from UAE service sector. J. Knowl. Manag. 2018, 22, 384-412. [CrossRef]

39. Kaba, A.; Ramaiah, C.K. Demographic differences in using knowledge creation tools among faculty members. J. Knowl. Manag. 2017, 21, 857-871. [CrossRef]

40. Rafique, M.; Hameed, S.; Agha, M.H. Impact of knowledge sharing, learning adaptability and organizational commitment on absorptive capacity in pharmaceutical firms based in Pakistan. J. Knowl. Manag. 2018, 22, 44-56. [CrossRef]

41. Youssef, M.; Haak-Saheem, W.; Youssef, E.M. A structural equation model for knowledge sharing behavior in an emerging economy. J. Knowl. Manag. 2017, 21, 925-945. [CrossRef]

42. Raudeliūnienè, J.; Davidavičienė, V.; Jakubavičius, A. Knowledge management process model. Entrep. Sustain. Issues 2018, 5, 542-554. [CrossRef]

43. Raudeliūnienè, J.; Szarucki, M. An Integrated Approach to Assessing an Organization\&rsquo;s Knowledge Potential. Eng. Econ. 2019, 30, 69-80. [CrossRef]

44. Raudeliūnienè, J. Organizacijos Žinių Potencialo Vertinimo Aktualijos Topicalities of the Organization's Knowledge Potential Assessment; Technika: Vilnius, Lithuania, 2017.

45. Raudeliuniene, J.; Albats, E.; Kordab, M. Impact of information technologies and social networks on knowledge management processes in Middle Eastern audit and consulting companies. J. Knowl. Manag. 2020, 1-28. [CrossRef]

46. Liu, S.; Deng, Z. Understanding Knowledge Management Capability in Business Process Outsourcing: A Cluster Analysis. Manag. Decis. 2015, 53, 124-138. [CrossRef]

47. Henttonen, K.; Kianto, A.; Ritala, P. Knowledge sharing and individual work performance: An empirical study of a public sector organisation. J. Knowl. Manag. 2016, 20, 749-768. [CrossRef]

48. Obeidat, B.Y.; Masa'Deh, R.M.T.; Abdallah, A.B. The Relationships among Human Resource Management Practices, Organizational Commitment, and Knowledge Management Processes: A Structural Equation Modeling Approach. Int. J. Bus. Manag. 2014, 9, 9. [CrossRef]

49. Dang, R.J.; McKelvey, M. Knowledge management processes and the formation of entrepreneurial opportunities. J. Innov. Econ. 2016, 19, 31. [CrossRef]

50. Pandey, S.C.; Dutta, A.; Nayak, A.K. Organizational capabilities and knowledge management success: A quartet of case studies. Kybernetes 2018, 47, 222-238. [CrossRef]

51. Dzenopoljac, V.; Alasadi, R.; Zaim, H.; Bontis, N. Impact of knowledge management processes on business performance: Evidence from Kuwait. Knowl. Process. Manag. 2018, 25, 77-87. [CrossRef]

52. Känsäkoski, H. Information and Knowledge Processes as a Knowledge Management Framework in Health Care: Towards Shared Decision Making? J. Doc. 2017, 73, 748-766. [CrossRef]

53. Ceptureanu, S.I.; Ceptureanu, E.G.; Olaru, M.; Popescu, D.I. An Exploratory Study on Knowledge Management Process Barriers in the Oil Industry. Energies 2018, 11, 1977. [CrossRef]

54. Sirorei, E.; Fombad, M.C. Knowledge management processes at St Paul's University Library in Kenya. SA J. Inf. Manag. 2019, 21, 1-8. [CrossRef]

55. Sangari, M.S.; Hosnavi, R.; Zahedi, M.R. The Impact of Knowledge Management Processes on Supply Chain Performance: An Empirical Study. Int. J. Logist. Manag. 2015, 26, 603-626. [CrossRef]

56. Shujahat, M.; Sousa, M.J.; Hussain, S.; Nawaz, F.; Wang, M.; Umer, M. Translating the impact of knowledge management processes into knowledge-based innovation: The neglected and mediating role of knowledge-worker productivity. J. Bus. Res. 2019, 94, 442-450. [CrossRef] 
57. Little, T.A.; Deokar, A.V. Understanding knowledge creation in the context of knowledge-intensive business processes. J. Knowl. Manag. 2016, 20, 858-879. [CrossRef]

58. Sumbal, M.S.; Tsui, E.; See-To, E.; Barendrecht, A. Knowledge retention and aging workforce in the oil and gas industry: A multi perspective study. J. Knowl. Manag. 2017, 21, 907-924. [CrossRef]

59. Antunes, H.D.J.G.; Pinheiro, P.G. Linking knowledge management, organizational learning and memory. J. Innov. Knowl. 2020, 5, 140-149. [CrossRef]

60. Hosseini, S.S.; Tekmedash, Y.N.; Karami, A.; Jabarzadeh, Y. The Impact of Knowledge Management Strategy on Service Innovation Performance in Private and Public Hospitals. Iran. J. Manag. Stud. 2019, 12, 1-24.

61. Marques, J.M.R.; la Falce, J.L.; Marques, F.M.F.R.; de Muylder, C.F.; Silva, J.T.M. The relationship between organizational commitment, knowledge transfer and knowledge management maturity. J. Knowl. Manag. 2019, 23, 489-507. [CrossRef]

62. Tangaraja, G.; Rasdi, R.M.; Ismail, M.; Abu Samah, B. Fostering knowledge sharing behaviour among public sector managers: A proposed model for the Malaysian public service. J. Knowl. Manag. 2015, 19, 121-140. [CrossRef]

63. Chhim, P.P.; Somers, T.M.; Chinnam, R.B. Knowledge reuse through electronic knowledge repositories: A multi theoretical study. J. Knowl. Manag. 2017, 21, 741-764. [CrossRef]

64. al Saifi, S.A. Positioning organisational culture in knowledge management research. J. Knowl. Manag. 2015, 19, 164-189. [CrossRef]

65. Kassab, A. Knowledge Management Practices in the Middle East: Challenges and Trends. Int. J. Innov. Knowl. Manag. Middle East N. Afr. 2016, 5, 71-80.

66. Akram, M.S.; Goraya, M.A.S.; Malik, A.; Aljarallah, A.M. Organizational Performance and Sustainability: Exploring the Roles of IT Capabilities and Knowledge Management Capabilities. Sustainability 2018, 10, 3816. [CrossRef]

67. Athayde, S.; Silva-Lugo, J.; Schmink, M.; Kaiabi, A.; Heckenberger, M. Reconnecting art and science for sustainability: Learning from indigenous knowledge through participatory action-research in the Amazon. Ecol. Soc. 2017, 22, 1-12. [CrossRef]

68. Martins, V.W.B.; Rampasso, I.S.; Anholon, R.; Quelhas, O.L.G.; Filho, W.L. Knowledge management in the context of sustainability: Literature review and opportunities for future research. J. Clean. Prod. 2019, 229, 489-500. [CrossRef]

69. Lemmetty, S.; Glăveanu, V.P.; Collin, K.; Forsman, P. (Un)Sustainable Creativity? Different Manager-Employee Perspectives in the Finnish Technology Sector. Sustainability 2020, 12, 3605. [CrossRef]

70. Zhang, Y.; Khan, U.; Lee, S.; Salik, M. The Influence of Management Innovation and Technological Innovation on Organization Performance. A Mediating Role of Sustainability. Sustainability 2019, 11, 495. [CrossRef]

71. de Pablos, P.O.; Lytras, M.D. Knowledge Management, Innovation and Big Data: Implications for Sustainability, Policy Making and Competitiveness. Sustainability 2018, 10, 2073. [CrossRef]

72. Caiado, R.G.G.; Quelhas, O.L.G.; Nascimento, L.M.; Anholon, R.; Filho, W.L. Measurement of Sustainability Performance in Brazilian Organizations Measurement of Sustainability Performance in Brazilian Organizations. Int. J. Sustain. Dev. World Ecol. 2018, 25, 312-326. [CrossRef]

73. Lega, F.; Prenestini, A.; Spurgeon, P. Is Management Essential to Improving the Performance and Sustainability of Health Care Systems and Organizations? A Systematic Review and a Roadmap for Future Studies. Value Health 2013, 16, S46-S51. [CrossRef]

74. Lee, S.H.; Ha-Brookshire, J. The effect of ethical climate and employees' organizational citizenship behavior on U.S. fashion retail organizations' sustainability performance. Corp. Soc. Responsib. Environ. Manag. 2018, 25, 939-947. [CrossRef]

75. Coutinho, V.; Domingues, A.R.; Caeiro, S.; Painho, M.; Antunes, P.; Santos, R.; Videira, N.; Walker, R.M.; Huisingh, D.; Ramos, T.B. Employee-Driven Sustainability Performance Assessment in Public Organisations. Corp. Soc. Responsib. Environ. Manag. 2017, 25, 29-46. [CrossRef]

76. Sindakis, S.; Depeige, A.; Anoyrkati, E. Customer-centered knowledge management: Challenges and implications for knowledge-based innovation in the public transport sector. J. Knowl. Manag. 2015, 19, 559-578. [CrossRef]

77. Lin, T.-C.; Chang, C.L.-h.; Tsai, W.-C. The Influences of Knowledge Loss and Knowledge Retention Mechanisms on the Absorptive Capacity and Performance of a MIS Department. Manag. Decis. 2016, 54, 1757-1787. [CrossRef] 
78. Bilan, Y.; Hussain, H.I.; Haseeb, M.; Kot, S. Sustainability and Economic Performance: Role of Organizational Learning and Innovation. Eng. Econ. 2020, 31, 93-103. [CrossRef]

79. Hutomo, A.; Haizam, M.; Sinaga, O. The Mediating Role of Organizational Learning Capability On Green Distribution and Green Packaging Towards Sustainability Performance as A Function Environmental Dynamism: Indonesia and Malaysia Fishery Industries. In Proceedings of the IOP Conference Series: Earth and Environmental Science, Kuala Lumpur, Malaysia, 16-18 January 2018; IOP Publishing: Bristol, UK, 2018; Volume 164, p. 012018.

80. Krafft, J.; Quatraro, F.; Saviotti, P.P. The Dynamics of Knowledge-intensive Sectors' Knowledge Base: Evidence from Biotechnology and Telecommunications. Ind. Innov. 2014, 21, 215-242. [CrossRef]

81. Balasubramanian, S.; Al-Ahbabi, S.; Sreejith, S. Knowledge Management Processes and Performance: The Impact of Ownership of Public Sector Organizations. Int. J. Public Sect. Manag. 2020, 33, 1-21. [CrossRef]

82. Buheji, M.J. Knowledge Management Influence on Government Organisations Competitiveness. Ph.D. Thesis, Brunel Business School, Brunel University London, Middlesex, UK, 2013.

83. Fullwood, R.; Rowley, J.; Delbridge, R. Knowledge sharing amongst academics in UK universities. J. Knowl. Manag. 2013, 17, 123-136. [CrossRef]

84. van Dijk, A.; Hendriks, P.; Romo-Leroux, I. Knowledge sharing and social capital in globally distributed execution. J. Knowl. Manag. 2016, 20, 327-343. [CrossRef]

85. Lin, H.-F. A stage model of knowledge management: An empirical investigation of process and effectiveness. J. Inf. Sci. 2007, 33, 643-659. [CrossRef]

86. Ramachandran, S.D.; Chong, S.C.; Ismail, H. The Practice of Knowledge Management Processes: A Comparative Study of Public and Private Higher Education Institutions in Malaysia. VINE 2009, 39, 203-222. [CrossRef]

87. Yusr, M.M.; Mokhtar, S.S.M.; Othman, A.R.; Sulaiman, Y. Does interaction between TQM practices and knowledge management processes enhance the innovation performance? Int. J. Qual. Reliab. Manag. 2017, 34, 955-974. [CrossRef]

88. Khosravi, A.; Razak, A.; Hussin, C.; Nilashi, M. Telematics and Informatics Toward Software Quality Enhancement by Customer Knowledge Management in Software Companies. Telemat. Inform. 2018, 35, 18-37. [CrossRef]

89. Mirzaee, S.; Ghaffari, A. Investigating the impact of information systems on knowledge sharing. J. Knowl. Manag. 2018, 22, 501-520. [CrossRef]

Publisher's Note: MDPI stays neutral with regard to jurisdictional claims in published maps and institutional affiliations.

(C) 2020 by the authors. Licensee MDPI, Basel, Switzerland. This article is an open access article distributed under the terms and conditions of the Creative Commons Attribution (CC BY) license (http://creativecommons.org/licenses/by/4.0/). 